\title{
Research on Tensile Behaviour of New Structural Material MoNiCa
}

\author{
Aliaksandr BAHDANOVICH ${ }^{3}$, Regita BENDIKIENE ${ }^{1}$, Ramunas CESNAVICIUS ${ }^{2}$, \\ Antanas CIUPLYS ${ }^{1 *}$, Vytautas GRIGAS ${ }^{2}$, Audrius JUTAS ${ }^{2}$, Dzianis MARMYSH ${ }^{3}$, \\ Aleh MAZALEUSKI ${ }^{3}$, Aleh NASAN ${ }^{3}$, Liudmila SHEMET ${ }^{3}$, Sergei SHERBAKOV ${ }^{3}$, \\ Kestutis SPAKAUSKAS ${ }^{2}$, Leonid SOSNOVSKIY ${ }^{4}$
}

\author{
${ }^{1}$ Department of Production Engineering, Faculty of Mechanical Engineering and Design, Kaunas University of Technology, \\ Studentu str. 56, 51424 Kaunas, Lithuania \\ ${ }^{2}$ Department of Mechanical Engineering, Faculty of Mechanical Engineering and Design, Kaunas University of \\ Technology, Studentu str. 56, 51424 Kaunas, Lithuania \\ ${ }^{3}$ Department of Theoretical and Applied Mechanics, Faculty of Mechanics and Mathematics, Belarusian State University, \\ Nezavisimosti ave 4, 220030 Minsk, Belarus \\ ${ }^{4}$ Department of Locomotives, Mechanical Faculty, Belarusian State University of Transport, Kirova str. 34, 246653 Gomel, \\ Belarus
}

crossref http:// dx.doi.org/10.5755/j01.ms.25.3.23079

Received 07 May 2019; accepted 06 June 2019

\begin{abstract}
This article presents the results of a set of innovative research to analyse a new structural material - steel like austempered ductile cast iron with mechanical properties similar to heat-treated steel, and with technological and exploitation characteristic close to high-strength cast iron with nodular graphite. Specific examples of its high efficiency for the manufacture of critical, mass and heavy-loaded components of modern machinery and equipment are presented. New structural material MoNiCa was tested on tension and was compared to commercial grades of austempered ductile cast irons and heat treated steels. Unconventional behaviour of examined material was observed: with tensile strength increase to almost $1600 \mathrm{MPa}$ the metal became less brittle. Hardness test revealed another distinctive feature of new material that there is no linear relation between strength and hardness increase, different hardness values $\sim 40 \mathrm{HRC}$ or $\sim 55 \mathrm{HRC}$ can be achieved with the same tensile strength 1000-1200 MPa. Microscopic analysis demonstrated of sophisticated structure formed owing to different regimes of austempering treatment. Specific properties emerged from successful ratio of three elements $\mathrm{Mo}, \mathrm{Ni}$, and $\mathrm{Cu}$ (carbon equivalent), and properly chosen heat treatment modes.

Keywords: austempered ductile cast iron, tensile strength, strength, ductility, hardness.
\end{abstract}

\section{INTRODUCTION}

Steel and cast iron are two classes of iron-carbon base alloys, the production of which to a certain extent determines the world technical progress over the past 200 years. The extent of production of these ferrous metals, despite the fact that there is a constant search for their substitutes - special non-ferrous alloys, powder materials, polymers, composites, etc., rise steadily $[1,2]$. There is a clear increase in the intensity of growth in the production of both steel and cast iron. However, extent of cast iron casting significantly inferior to the production of steel, what is obviously. The last decades could be characterized by a significant increase in productivity, high rate of production, work load of machines and equipment, which is ensured by inadequate increase in the strength of the materials used to manufacture their most relevant elements and systems. Meanwhile, the strength properties of cast iron are relatively low compared to steel. The application of high-strength cast irons (with a tensile strength of $\sim \sigma_{\mathrm{u}}<800 \mathrm{MPa}$ ) led to the reduction of cast iron/steel production ratio dropped down and later have been stabilized. But when high-strength cast irons with nodular and vermicular graphite were developed, the strength of which exceeded $1000 \mathrm{MPa}$ range, the situation changed: the ratio of cast iron/steel production picked up. Thereby, the perspective of using such cast irons for the manufacture of elements for the massive and heavily loaded systems of machines (so called power machines) and equipment have been enabled. Any mechanical system which receives and transmits repeatedly varying load and in which the process of friction during sliding, rolling, slipping (fretting), impact, etc. occurs simultaneously is called a power system. In other words, the power system is a pair of friction, at least one of the elements of which works in conditions of volume fatigue. As power system is recognized as any system under the mechanical load, experts suggested a strict term tribo-fatigue system (TFS), which nowadays is widely used to characterise severe loading working conditions [3].

At the beginning of recent century, in connection with the transition of Production Group "GOMSELMASH" (Republic of Belarus) to the production of modern highperformance self-propelled combine harvesters for agricultural application, experts of company also joined to the competitive "struggle" of iron and steel in order to use the high-strength nodular graphite cast iron as a structural material for TFS. This seemed to be necessary because of

\footnotetext{
*Corresponding author. Tel.: +370-37-323769; fax: +370-37-324144.

E-mail address: antanas.ciuplys@ktu.lt (A. Ciuplys)
} 
three main reasons. Firstly, cast iron, possesses a number of undoubtedly higher technological and service properties than steel (Table 1) [4]. Secondly, the energy savings only when replacing steel with cast iron can reach $50 \%$ or even more (Table 2) [5]. And finally, the perspective of transition from high-energy and high-cost press-forging and welding technologies for the manufacture of complex structural elements to high-quality casting technology is recognized technologically and economically very profitable worldwide.

Table 1. Comparison of the properties of austempered ductile cast iron ADI-1050 and steel 42CrMo4

\begin{tabular}{|l|c|c|}
\hline Properties & 42CrMo4 & ADI-1050 \\
\hline Tensile strength, MPa & 1000 & 1050 \\
\hline Plasticity limit, MPa & 750 & 700 \\
\hline Elongation, \% & 11 & 7 \\
\hline Modulus of elasticity, kN/mm ${ }^{2}$ & 210 & 170 \\
\hline Hardness, HB & 300 & $302-363$ \\
\hline Impact strength, (J) & 40 & 10 \\
\hline Fatigue limit, MPa & 500 & 400 \\
\hline Wear resistance & low & high \\
\hline Damping ability & low & high \\
\hline Fluidity & low & high \\
\hline Density, g/cm ${ }^{3}$ & 7.9 & 7.2 \\
\hline Self-lubrication ability & low & high \\
\hline Effect of wall thickness & high & low \\
\hline Cost, \% & 100 & $40-80$ \\
\hline
\end{tabular}

Table 2. Comparison of energy consumption in the process of manufacturing parts from cast iron ADI-1050 (austempered ductile iron) and steel $42 \mathrm{CrMo} 4$

\begin{tabular}{|c|c|c|}
\hline \multirow{2}{*}{$\begin{array}{l}\text { Electricity consumption, } \\
\mathrm{kWh} / \mathrm{t}\end{array}$} & \multicolumn{2}{|c|}{ Material } \\
\hline & $42 \mathrm{CrMo} 4$ & ADI-1050 \\
\hline Recovery of material & 4500 & 2500 \\
\hline Pre-treatment & 500 & - \\
\hline Austempering & - & 600 \\
\hline Hardening & $800-1200$ & \\
\hline Total: & $5800-6200$ & 3100 \\
\hline
\end{tabular}

The main aim of this research was to test and compare the behaviour of new structural material MoNiCa to commercial grades of austempered ductile cast iron sand case hardened steels under the same tension conditions. Considering that the production of cast iron is cost effective, it can be decided to replace alloyed steel by new structural material for usage in severe wear applications. After the experiments, presumption to use this material for possible tribo-fatigue systems has been analysed.

\section{MATERIALS AND METHODS}

Two types of reference commercial materials case hardened steels and austempered ductile cast irons (ADI) were selected to be compared to new structural material MoNiCa. The former was chosen because of its suitability for manufacturing of cemented critical parts, which require increased strength and toughness of the core, as well as high surface hardness, working under the shock loads. The lower bainite structure of the later assures high contact fatigue strength (1020 - $1260 \mathrm{MPa})$ which exceeds contact strength of carbon, alloyed, nitride and hardened steels, but stays behind case hardened steels $(1260-1630 \mathrm{MPa})$. The chemical composition of MoNiCa is shown in Table 3.

Table 3. Chemical composition of MoNiCa, wt.\% [6]

\begin{tabular}{|c|c|c|c|c|}
\hline $\mathrm{C}$ & $\mathrm{Si}$ & $\mathrm{Mn}$ & $\mathrm{Cr}$ & $\mathrm{Mo}$ \\
\hline $3.5-3.7$ & $2.5-2.8$ & $0.2-0.3$ & $0.02-0.06$ & $0.4-0.6$ \\
\hline $\mathrm{Ni}$ & $\mathrm{Cu}$ & $\mathrm{Mg}$ & $\mathrm{Ti}$ & $\mathrm{Fe}$ \\
\hline $0.5-0.6$ & $1.1-1.3$ & $0.03-0.07$ & $0.01-0.12$ & Bal. \\
\hline
\end{tabular}

Heat treatment was used to modify resultant structure in order to achieve the highest mechanical strength accompanying by steel-like ductility. Such a treatment requires an interrupted quenching, usually performed into a salt bath, to cool the casting at a defined rate with long enough duration to reach the desired austempering effect $[7,8]$. The resultant alloy has a combination of exceptional strength and toughness, meeting or even exceeding those of alloyed steels. The cycle of austempering treatment is shown in Fig. 1. The test samples made of MoNiCa were austenized at $890{ }^{\circ} \mathrm{C}$ for $\sim 30 \mathrm{~min}$ in a furnace. The austenitizing temperatures were chosen in order to austenitize completely the entire test sample. Afterwards, they underwent austempering, an isothermal heat treatment process, in which test samples are quenched in a molten salt bath of sodium and potassium nitrate salts (potassium nitrate $\mathrm{KNO}_{3}-50 \%$ GOST 19790-74, sodium nitrate $\mathrm{NaNO}_{3}-25 \%$ GOST 4168-79, sodium nitrite $\mathrm{NaNO}_{2}-25 \%$ GOST 19906-74). The test samples were transferred from a high temperature to the quench bath within $5 \mathrm{~s}$, to ensure formation of upper or lower bainite. Austempering was done at different temperatures: $330^{\circ} \mathrm{C}$, $300^{\circ} \mathrm{C}$ and $270^{\circ} \mathrm{C}$, in order to study the influence of the process temperature on tensile strength-ductility ratio and the evolution of microstructure.

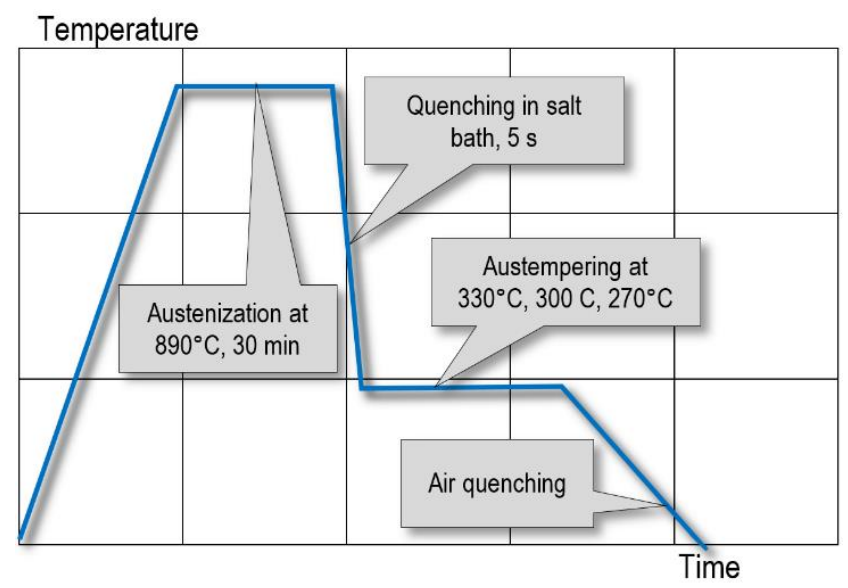

Fig. 1. Schematic illustration of heat treatment cycle of new structural material MoNiCa

Austempering time plays huge role on the formation of properties and structure of austempered cast irons. If process time is too short, the hardness of resultant structure reaches high values with low values of toughness and ductility. In the case of too long duration of austempering lower hardness, strength, fracture toughness and ductility exhibits. At the temperature of $330{ }^{\circ} \mathrm{C}$ more than half an hour is enough to reach necessary structure, while lowest process temperature $270{ }^{\circ} \mathrm{C}$ requires more than $1 \mathrm{~h}[7,9,10]$. 
Tensile tests were accomplished using multifunctional servohydraulic testing machine LFV100, Walter-Bai AG, Switzerland. The maximum load in static mode is $\pm 120 \mathrm{kN}$, in dynamic mode $\pm 100 \mathrm{kN}$ accuracy class 0.5 , the frequency range in dynamic mode is $0.001-100 \mathrm{~Hz}$, the height of the test area is up to $800 \mathrm{~mm}$. Tensile test pieces with $50 \mathrm{~mm}$ of gauge length and $8 \mathrm{~mm}$ in diameter were prepared for analysis. Detailed dimensions of test piece geometry provided in Fig. 2.

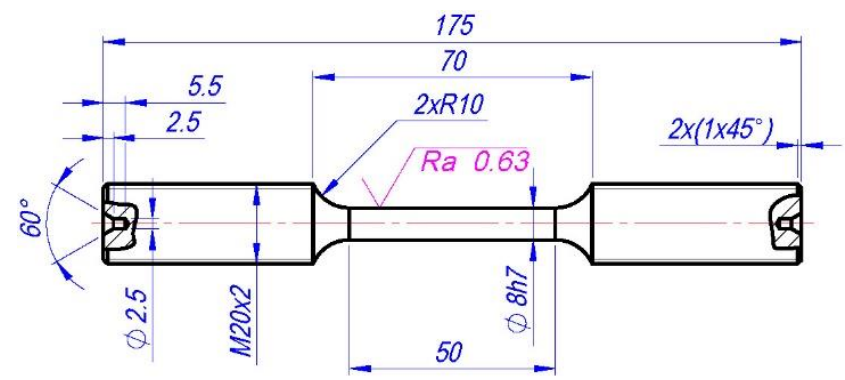

Fig. 2. Geometry of tensile test piece

The test was executed at ambient temperature. Tensile test pieces were tested in each austempering conditions.

The effect of austenization and austempering at different temperatures on microstructure and properties of new structural material was also studied. Microstructural analysis was done on test samples prepared of heat treated MoNiCa by grinding using different roughness of emery paper, fine polishing to a near mirror finish, and etching using $2 \%$ Nital solution; micro analysis was performed on MLA 10 and Carl ZeisAxio Scope A1.

Brinell and Rockwell hardness tests were accomplished on the as-cast and austempered test samples using Universal hardness tester Verzus 750CCD.

\section{RESULTS AND DISCUSSION}

It is well known that the mechanical properties such as strength, hardness and fatigue resistance of any metal is largely determined by its structure. Fig. 3 depicts huge possibilities of varying mechanical strength by heat treatment and formation of the relevant structure of the new structural material MoNiCa.

Fig. 3 a shows as-cast microstructure of new structural material which mainly consists of pearlite, ferrite and nodular graphite. Roundness of graphite nodules in as-cast state is highly expressed [11].

Fig. $3 \mathrm{a}$ and $\mathrm{b}$ depicts two-phase base consisting of bainite (upper in Fig. 3 b, lower in Fig. 3 c) and retained austenite. Different austempering temperatures leads to the formation of coarse and fine grained structures; while testing on tension test samples treated according to austempering schedule achieved results exceeded expectations: tensile strength of as-cast condition was $800 \mathrm{MPa}$, austempering treatment induced increase of values to $1250 \mathrm{MPa}$ and $1400 \mathrm{MPa}$ respectively.

Image shown in Fig. 3 d reveals typical characteristic of tempered martensite morphology [12]. It can be explained by lower austempering treatment temperature which causes the decarburization of martensitic base as free carbon atoms reacts with carbides forming elements and formed granular carbides.

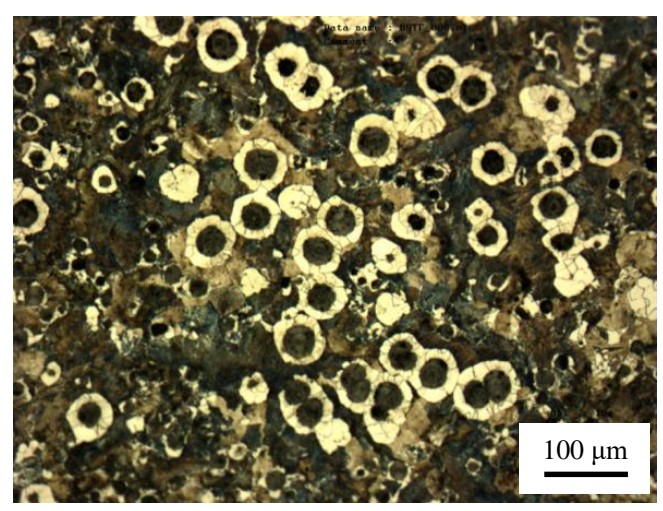

a

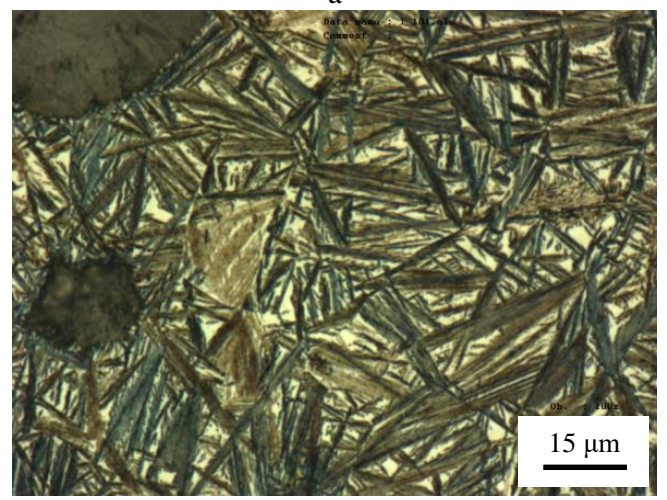

b
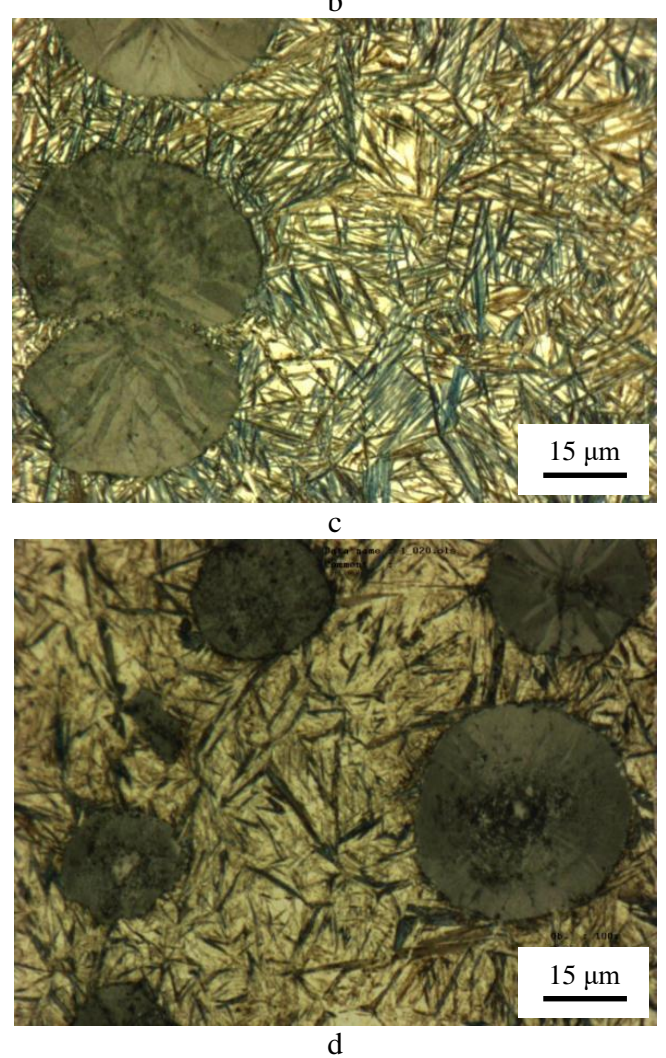

Fig. 3. The main structural states of MoNiCa after heat treatment process: a-ferrite + pearlite, austenite, carbides (as cast); $\mathrm{b}$-upper bainite, retained austenite; $\mathrm{c}$-lower bainite, retained austenite; $\mathrm{d}$-martensite, retained austenite, carbides

Thus, from the images in Fig. 3 it can be concluded that the structure of the MoNiCa is neither bainitic, nor martensitic, nor ferritic-pearlitic; it is a special cast iron, 
which, depending on the modes of heat treatment, can demonstrate various and diverse structural states similar to the microstructure of steel. According to comparative study of reference materials and new structural material tensile strength' it was deduced that ductile cast iron with specific properties is not just a high-durable $\left(\sigma_{\mathrm{u}}<<1000 \mathrm{MPa}\right)$ but alloy which possesses extremely high strength, since its strength not only reaches, but also significantly exceeds the "red border" ( $\sigma_{\mathrm{u}}=1000 \mathrm{MPa}$, see Fig. 4).

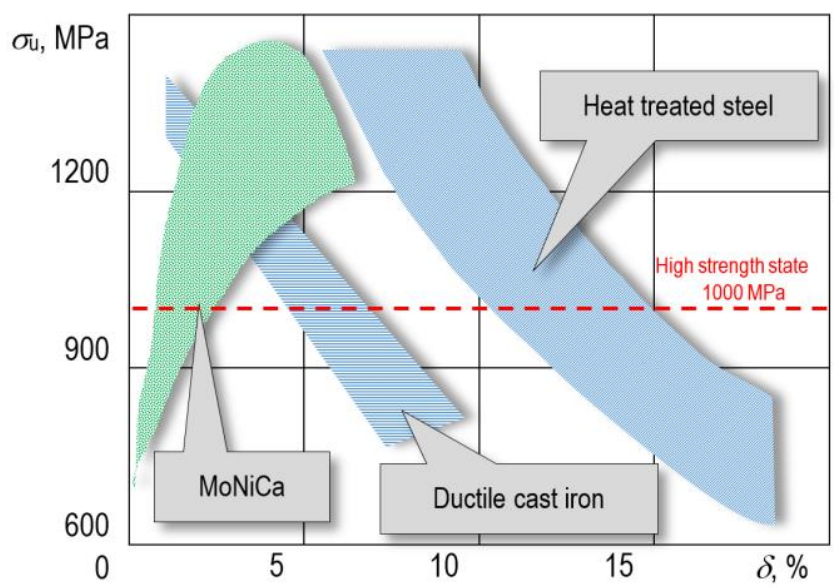

Fig. 4. Comparison of tensile strength-ductility ratio: new structural material MoNiCa via commercial steels and cast irons

From physical point of view cast iron MoNiCa revealed an important feature: owing to heat treatment conditions it can attain different microstructures (Fig. 3) or their necessary mixture, at the same time showing a big range of tensile strength values from 800 to $1600 \mathrm{MPa}$. Mechanical point of view characterise material by surprising behaviour during tensile test (Fig. 4). Traditionally strength rise of any material is followed by ductile-to-brittle transition, i.e. ductility gradually decreases (hatched sections in Fig. 4), in other words the metal becomes brittle. Tendency of cast iron MoNiCa behaviour totally different: with strength increasing the metal became less brittle, opposite transition brittle-to-ductile was observed. Along to different transition pattern, new structural material showed other nonconventional behaviour: while strength of common alloys increases hardness increases as well, whereas for $\mathrm{MoNiCa}$ this trend is a bit different. It is possible to obtain hardness values of $35-40 \mathrm{HRC}$ when the tensile strength is $1000-1200 \mathrm{MPa}$, if required, applying appropriate heat treatment the hardness values can reach 50-55 HRC for the same strength.

The reason of this behaviour can be explained firstly by overall chemical composition with relation to carbon equivalent: the carbon equivalent of majority commercial cast irons considerably lower that of MoNiCa [13, 14]. Secondly, it is especially important that new structural material has an original and successful ratio of the triad of alloying additives Mo-Ni-Cu (Eq. 1).

$$
\begin{aligned}
& C_{\text {eq }}=\sum \frac{\text { atm. } \% C}{\text { atm. } \% \text { element } X} X \%=C \frac{12}{12}+S i \frac{12}{28}+M n \frac{12}{55}+ \\
& M g \frac{12}{24}+N i \frac{12}{59}+M o \frac{12}{96}+C u \frac{12}{64}+C r \frac{12}{52}
\end{aligned}
$$

In this regards the new structural material was named as MoNiCa (Mo, Ni, and $\mathrm{Cu}$ ) - steel-like high strength ductile cast iron. It is worth mentioning that in the last century the term steel-like was referred to ordinary gray cast iron with a reduced carbon content produced adding some steel to the melt.

\section{CONCLUSIONS}

The research showed that new structural material MoNiCa has only one serious competitor in tensile strengthductility study: case hardened steel. MoNiCa showed tensile strength increase to almost $1600 \mathrm{MPa}$, what is usually particular property of heat treated steels, which was reached after mindfully chosen austempering process parameters: temperature $270{ }^{\circ} \mathrm{C}, 300{ }^{\circ} \mathrm{C}$, and $330 \mathrm{C}$. After such a treatment the metal became less brittle. Hardness test revealed another distinctive feature of new material that there is no linear relation between strength and hardness increase, different hardness values $\sim 40 \mathrm{HRC}$ or $\sim 55 \mathrm{HRC}$ can be achieved with the same tensile strength $1000-1200 \mathrm{MPa}$. Microscopic analysis demonstrated of sophisticated structure formed owing to different regimes of austempering treatment. Specific properties emerged from successful ratio of three elements $\mathrm{Mo}, \mathrm{Ni}$, and $\mathrm{Cu}$ (carbon equivalent), and properly chosen heat treatment modes. As energy consumption to produce any kind of steel is almost two times higher than of austempered ductile cast iron, it is worth discussing the possibility to replace some components made of steel by new structural material. Therefore, future studies will be concentrated on wear test in tribo-fatigue system in order to evaluate behaviour of MoNiCa during exploitation.

\section{Acknowledgments}

This research was funded by a grant (No. S-LB-19-6) from the Research Council of Lithuania. This research was performed in cooperation with the Belarusian State University.

\section{REFERENCES}

1. Yu, Y., Chen, Z., Wei, L., Wang, B. The Low-carbon Technology Characteristics of China's Ferrous Metal Industry Journal of Cleaner Production 140 2017: pp. 1739-1748. https://doi.org/10.1016/j.jclepro.2016.05.136

2. Feng, Ch., Huang, J.B., Wang, M. The Sustainability of China's Metal Industries: Features, Challenges and Future Focuses Resources Policy 60 2019: pp. 215-224. https://doi.org/10.1016/j.resourpol.2018.12.006

3. Sosnovskiy, L.A., Bogdanovich, A.V., Yelovoy, O.M., Tyurin, S.A., Komissarov, V.V., Sherbakov, S.S. Methods and Main Results of Tribo-fatigue International Journal of Fatigue 66 2014: pp. 207-219. https://doi.org/10.1016/j.ijfatigue.2014.04.006

4. Campbell, J. Complete Casting Handbook - Metal Cating Processes, Metallurgy, Techniques and Design $2^{\text {nd }}$ Edition. Butterworth-Heinemann, Elsevier, 2015: pp. 1054. https://doi.org/10.1016/C2014-0-01548-1

5. Schifo, J.F., Radia, J.T. Theoretical/Best Practice Energy Use in Metal Casting Operations. Keramida Environmental, Indianapolis, 2004: pp. 55-60. 
6. МКС 77.080.10; 77.040. High Fatigue Resistance Ductile Cast Iron with Nodular Shaped Graphite. Material Standard (in Russian).

7. Sellamuthu, P., Harris Samuel, D.G., Dinakaran, D., Premkumar, V.P., Li, Z., Seetharaman, S. Austempered Ductile Iron (ADI): Influence of Austempering Temperature on Microstructure, Mechanical and Wear Properties and Energy Consumption Metals 8(1) 53 2018: pp. 1-12. https://doi.org/10.3390/met8010053

8. Zhang, N., Zhang, J., Lu, L., Zhang, M., Zeng, D., Song, Q. Wear and Friction Behaviour of Austempered Ductile Iron as Railway Wheel Material Materials and Design 89 2016: pp. 815-822. https://doi.org/10.1016/j.matdes.2015.10.037

9. Guerra, L.F.V., Jacuinde, A.B., Mejia, I., Zuno, J., Maldonado, C. Effects of Boron Addition and Austempering Time on Microstructure, Hardness and Tensile Properties of Ductile Irons Materials Science and Engineering A 648 2015: pp. $193-201$. https://doi.org/10.1016/j.msea.2015.09.066

10. Dias, J.F., Ribeiro, G.O., Carmo, D.J., Vilela, J.J. The Effect of Reducing the Austempering Time on the Fatigue
Properties of Austempered Ductile Iron Materials Science and Engineering A 556 2012: pp. 408-413.

https://doi.org/10.1016/j.msea.2012.07.005

11. Panneerselvan, S., Putatunda, S.K. Processing of Nanostructured Austempered Ductile Cast Iron (ADI) by a Novel Method International Journal of Metallurgy and Metal Physics 3 (2) 2018: pp. 1-11.

12. Li, Y., Li, P., Wang, K., Li, H., Gong, M., Tong, W. Microstructure and Mechanical Properties of a Mo Alloyed High Chromium Cast Iron after Different Heat Treatments Vacuum 156 2018: pp. 59-67. https://doi.org/10.1016/j.vacuum.2018.07.013

13. Bazhenov, V.E., Pikunov, M.V. Determining the Carbon Equivalent of Cast Iron by the Thermo-Calc Program Steel in Translation 41 (11) 2011: pp. 896-899.

14. Rosa, L.G., Margarido, F. Effect of Carbon Equivalent on Graphite Formation in Heavy-Section Ductile Iron Parts Materials Science Forum 636-637 2010: pp. 523-530. https://doi.org/10.4028/www.scientific.net/MSF.636637.523 